\title{
ANALISA KEKUATAN DAN KETAHANAN LUNTUR KAIN LORENG "INDIAN ARMY" BERBASIS STANDAR NASIONAL INDONESIA
}

\author{
Budhiman Adi Setyawan ${ }^{1)}$, Lomo Mula Tua ${ }^{2)}$ \\ Jurusan Teknik Perkapalan-Fakultas Teknik UPN."Veteran" Jakarta \\ Jl.RS.Fatmawati Pondok Labu Jakarta Selatan 12450 \\ Telp.0217662056 \\ e-mail : budhimanadisetyawan9@gmail.com ${ }^{l)}$
}

\begin{abstract}
"The Indian Army" is clothing camouflage used by one of mass organization in Indonesia. It has a different function than TNI camouflage's nevertheless must passed from The SNI examination. They are thirdteen standard qualifications must be passed. Those are the wight of cloth (SNI ISO $3801: 2010$ ) $238.4 \mathrm{~g} / \mathrm{m}^{2}$, the cloth construction (SNI ISO 7211-2:2010) the total of warp is $42.8 \mathrm{yarn} / \mathrm{cm}$ and woof is $24.4 \mathrm{yarn} / \mathrm{cm}$, The yarn number of warp and woof (SNI ISO 7211-5:2010) $\mathrm{Ne}_{1}$ 40.2/2 and $\mathrm{Ne}_{1}$ 15, The plaiting (SNI ISO 7211-1:2010) is plat/ribstop, The stress-strain of cloth (SNI 0276:2009) (the stress of warp is $42.8 \mathrm{kgs}$ and woof direction is 26.42 $\mathrm{kgs}$ and the strain of warp is $23,71 \%$ and woof is $12,20 \%$ ), The strengthness to a torn piece of cloth (SNI ISO 13937-1:2013) for the warp direction is 4,490 gms dan woof is 3,250 gms, The composition of cloth (SNI 08-0265: 1989) the cotton is $60.2 \%$ and the polyester is $39.8 \%$, Colourfastness to washing (SNI ISO 105-C06:2010) is 4 GS/SS, to crocking (SNI 0288 : 2008) is 2-3 in wet and 3-4 in dry crocking, to sweat (SNI ISO 105-E04 : 2010) is 4, Light (SNI 080289:1996) is 4 for BWS and catagory of dyestuff (SNI 08-0519:1989) is the dispers dyes and (SNI 08-0621:1989) is the vat dyes. "The Indian Army" passed on the twelve of standards except one that is SNI 0288:2008 (the colourfastness to crocking). The conclution that the Indian Army is not accepted yet
\end{abstract}

Keywords : The Indian Army, SNI, ISO

\section{Pendahuluan}

Dewasa ini pemakaian kain loreng sebagai salah satu pakaian seragam militer telah disalahgunakan oleh masyarakat baik sebagai pakaian sehari-hari (fashion) perseorangan maupun seragam resmi kelompok atau organisasi kemasyarakatan untuk menunjukkan eksistensi mereka di tengah-tengah kehidupan bermasyarakat, berbangsa dan bernegara. Sebenarnya penggunaan seragam dan atribut militer baik yang loreng ataupun yang bukan loreng dilarang dipakai oleh siapapun dan oleh organisasi apapun di dalam wilayah Negara Kesatuan Republik Indonesia ini. Namun faktanya ternyata masyarakat telah terangterangan menggunakan seragam loreng yang seharusnya hanya dipakai oleh militer (TNI) dipakai juga oleh perorangan ataupun organisasi kemasyarakatan dari yang coraknya berbeda sama sekali sampai pada corak yang mirip,mendekati atau sama dengan corak dari loreng militer (TNI). Sekali lagi, apapun coraknya pemakaian kain loreng di luar institusi atau kepentingan militer (TNI) tetap dilarang.
Memang banyak orang yang mempunyai kepentingan dari seragam loreng ini. Ada yang berkepentingan untuk bisnis saja. Ada pula yang sekadar hobby bahkan ada yang menggunakannya untuk kepentingan politik. Ternyata pemakaian loreng untuk kepentingan politik jauh lebih banyak dari pada yang lainnya. Banyak organisasi kemasyarakatan atau organisasi massa baik yang independen maupun yang menjadi ormas partai politik menggunakan seragam loreng yang meskipun coraknya tidak sama tetapi sekurang-kurangnya menyerupai loreng TNI. Jika ada kelompok masyarakat yang menggunakan seragam loreng menyerupai seragam loreng yang dipakai oleh TNI dikhawatirkan akan terjadi kesalahpahaman di lapangan. Oleh sebab itu perlu ada langkahlangkah atau tindakan yang intinya mengembalikan pemakaian seragam loreng kepada TNI sebagai satu-satunya institusi yang berhak memakai loreng di seluruh wilayah Negara Kesatuan Republik Indonesia. Hasil survai pendahuluan menunjukkan adanya informasi bahwa para pemilik industri tekstil 
lokal dalam negeri belum pernah menerima permintaan pembuatan kain loreng dari kalangan swasta kecuali dari pemerintah (Mabes TNI). Timbul pertanyaan sekarang, jika tidak ada industri tekstil di dalam negeri yang mendapat order pembuatan kain loreng lantas dari mana kelompok-kelompok masyarakat itu mendapatkannya ?. Jawabannya pasti dari luar negeri (impor). Kain loreng masuk secara ilegal ke dalam negeri yang dilakukan oleh oknumoknum importir nakal. Kain-kain loreng eks impor yang biasa dipakai pasukan PBB (UN Military Staff),US Army/Navy, Korean Army, Indian Army dan lain-lain banyak ditemukan di Bandung yang dijual secara bebas.Akibat dari perdagangan yang terbuka ini,pemakaian loreng di luar institusi TNI seakan-akan tidak dilarang sehingga masyarakat dapat membeli dan memakainya tanpa ada perasaan takut. Bahkan, masyarakat dapat membeli kain loreng dengan berbagai corak sama seperti halnya membeli bahan tekstil untuk fashion, seragam sekolah, seragam kerja, pakaian sehari-hari dsb.

Industri tekstil Indonesia telah lama mendapatkan kepercayaan dari luar negeri dalam pembuatan seragam militer dan sipil NATO dalam jumlah yang banyak. Peluang bisnis ini tidak boleh diabaikan begitu saja. Bukan hanya nilai materinya saja akan tetapi nilai non-material juga penting. Terbukti setelah itu berdatangan order pembuatan seragam militer dari beberapa negara sahabat ke Indonesia seperti dari Afrika, Malaysia, Timor Leste dan lain lain. Secara teknis pembuatan seragam militer lebih menekankan pada kualitas produk yang tinggi karena penggunaannya yang berbeda dengan bahan tekstil pada umumnya. Oleh karena itu material bahan baku dan pendukung yang digunakan harus bermutu dan proses produksinyapun harus dikelola secara profesional dengan pengawasan yang ketat.

Disisi lain, dalam upaya kemandirian industri pertahanan akan kebutuhan alutsista dan peralatan pendukung yang tidak bergantung kepada luar negeri menjadi perhatian penting. Salah satu kebutuhan peralatan pendukung adalah kain loreng militer yang sudah bisa diproduksi secara nasional. Namun banyak kain loreng yang diproduksi tidak memenuhi kualitas yang diharapkan yaitu yang memenuhi persyaratan Standar Nasional Indonesia (SNI).
Suatu hipotesis dari kasus ini dapatkah kain loreng "Indian Army" memenuhi persyaratan Standar Nasional Indonesia (SNI)?

\section{Tinjauan Pustaka}

Sejak kapan waktu tepatnya masyarakat baik perorangan maupun kelompok kelompok organisasi masa mulai menggunakan seragam loreng sebagai pakaian seragam lapangan tidak diketahui secara pasti.Namun dari suatu peristiwa penting yang terjadi di tanah air yang menorehkan sejarah perjalanan bangsa Indonesia yaitu sebuah peristiwa yang hampir saja mengubah ideologi negara Pancasila dengan ideologi lain, kiranya peristiwa itu dapatlah dijadikan pegangan bahwa saat itulah masyarakat mulai menggunakan loreng sebagai salah satu pakaian yang

dipakai sebagai pakaian seragam mereka.Saat yang dimaksudkan adalah peristiwa G-30 S/PKI. Setelah terjadinya kudeta yang gagal yang dilakukan oleh PKI maka masyarakat bersama-sama dengan ABRI melakukan pembersihan terhadap para anggota PKI di seluruh tanah air. ABRI memberikan sebagian seragam loreng kepada para pemuda sebagai anggota kelompok masyarakat yang ikut operasi untuk menandakan/membedakan antara kelompok masyarakat yang pro pancasila dengan yang anti pancasila (PKI). Pemberian seragam loreng ini dimaksudkan untuk memotivasi rasa nasionalisme, kejuangan, bela negara, patriotik-heroisme para pemuda di dalam rangka menegakkan negara pancasila. Salah satu organisasi masa yang militan pada saat itu adalah Gerakan Pemuda Ansor yang secara aktif ikut melakukan operasi pemberantasan pemberontak G 30 S PKI yang berbasis di Jawa Timur. Sebagai akibat dari hubungan yang sangat dekat antara ABRI dengan masyarakat pada saat itu maka seolaholah pemakaian loreng oleh masyarakat dibolehkan seterusnya. Karena setelah ABRI berhasil menguasai keadaan dan situasi kondisi telah aman ternyata seragam loreng tidak ditarik lagi. Masyarakat dibiarkan menggunakan seragam loreng tanpa rasa takut justru semakin tumbuh rasa kebanggaan dan kecintaannya pada tanah air Indonesia. Ternyata, loreng bisa mempersatukan ABRI dengan para pemuda pada saat situasi yang sangat genting. Waktu terus berjalan dan dinamika kehidupan terus berkembang seiring dengan perkembangan 
kehidupan bermasyarakat, berbangsa dan bernegara yang semakin kondusif terkendali. Demikian pula halnya dengan kehidupan organisasi masa yang terus tumbuh menjamur dimana mana seiring dengan situasi politik,ekonomi sosial,budaya,pertahanan dan keamanan yang terus membaik. Beberapa organisasi masa yang mulai terdengar kiprahnya pada saat itu antara lain Pemuda Pancasila, AMPI,BANSER,Angkatan Muda Siliwangi, Pemuda Kosgoro, Pemuda Marhaen, FKPPI,Baladika Karya dan lain-lain. Pada umumnya sebagian besar organisasi masa mempunyai seragam loreng yang menjadi ciri khas organisasi yang berbeda satu dengan yang lainnya sampai sekarang.Berbeda halnya dengan seragam loreng TNI yang selalu dihubungkan dengan tuntutan kualitas yang nyata maka seragam loreng yang digunakan organisasi masa kiranya tuntutan kualitas tidaklah penting, karena penggunaan loreng bagi mereka bukanlah seperti halnya TNI yang tujuan utamanya adalah untuk penyamaran atau perang. Seragam loreng bagi organisasi masa tidak bedanya dengan pakaian fashion biasa saja karena hanya dipakai untuk

show of force atau hanya bergagahgagahan saja bukan untuk perang.Jadi,kualitas bukan menjadi prioritas utama tetapi yang utama adalah keunikan atau kekhasan corak dari loreng yang dimiliki. Semakin unik corak loreng dari suatu ormas maka identitas suatu ormas akan semakin mudah dikenali oleh masyarakat. Contohnya seragam loreng dari ormas Pemuda Pancasila mempunyai corak yang terang dan sangat kontras sekali sehingga tidak cocok untuk penyamaran/camouflage. Karena ada perbedaan didalam fungsinya itu maka ada sebagian ormas yang berpendapat bahwa kualitas seragam yang dipakai oleh sebagian besar ormas memang beda dengan kain loreng yang digunakan oleh TNI. Pendapat ini sebenarnya tidak tepat karena walaupun ada perbedaan fungsi diantara keduanya, kualitas harus tetap dijaga karena akan mempengaruhi nama baik ormas itu sendiri. Setiap kain loreng yang ada di wilayah NKRI haruslah memenuhi standar kualitas yang ada yaitu berdasarkan Standar Nasional Indonesia (SNI). Oleh karena itu perlu dilakukan pemeriksaan dan pengujian terhadap kualitas seragam loreng yang dipakai oleh organisasi di luar TNI agar dapat diketahui sejauh mana kualitas yang dimilikinya.
Kain loreng untuk konsumsi militer biasanya terbuat dari bahan dasar serat campuran kapas dan polyester $(\mathrm{C} / \mathrm{T})$. Komposisi ini dimaksudkan agar diperoleh kain yang kuat, tidak mudah kusut tetapi tidak panas. Serat kapas yang dipilih tentunya berasal dari serat yang berkualitas baik untuk mengimbangi kualitas serat poliester agar didapat kain yang bermutu baik. Serat kapas yang berkualitas baik biasanya mempunyai ciri-ciri seperti warnanya putih,panjang seratnya (minimal) 1,25 inci, kadar selulosanya tinggi ( $>95$ persen) dan halus. Proses pembuatan kain loreng terdiri dari beberapa tahap dinama setiap tahapnya ada pengawasan mutu.

Tahap yang pertama adalah pemintalan benang (spinning) yang akan membentuk satu konstruksi kain dengan disain khusus.Benangbenang pakan dan lusi harus terbuat dari serat kapas dan poliester yang bermutu baik. Disain khusus ini dimaksudkan agar tujuan utama dari penggunaan kain loreng yaitu agar kekuatan dan ketahanan luntur warnanya bisa memenuhi persyaratan SNI disamping aspek fashion. Salah satu faktor yang paling penting di dalam memperoleh kain dengan kekuatan tarik dan mulur yang tinggi adalah pada konstruksinya.

Konstruksi kain terdiri dari :

1. Nomor benang (lusi/pakan) yang menyatakan kehalusan benang.

Sering kali untuk mendapatkan kekuatan tarik dan mulur yang maksimal benang lusi mengalami perangkapan sehingga nomor benang lusi dan pakan menjadi tak sama.Nomor benang biasanya dinyatakan dalam $\mathrm{Ne}_{1}$ (Inggris) atau Tex (Jerman)

2. Tetal (lusi/pakan) yaitu kerapatan benangbenang lusi dan pakan dalam satuan luas tertentu. Tetal yang semakin rapat akan menunjukkan kekuatan yang tinggi tetapi mulurnya rendah sedangkan tetal yang jarang akan membuat kekuatan kain menjadi lemah tetapi mulurnya tinggi. Karena penggunaan kain loreng dituntut harus fleksibel maka tetal benang tidak boleh terlalu banyak ataupun sedikit sehingga tidak kaku dan mulurnya cukup.

3. Bentuk anyaman (plat,satyn atau keper). Untuk mendapatkan kain yang kokoh dipilih anyaman plat yaitu suatu anyaman yang terbentuk dari persilangan lusi dan pakan secara selang seling dimana posisi benang 
lusi sekali diatas dan sekali dibawah. Semakin halus kain itu dapat dibuat,kualitas kain akan semakin baik karena terbuat dari bahan dasar serat-serat yang sangat halus dan kuat. Secara ekonomis, ongkos produksinya akan semakin mahal dan harga jualnya pun akan menjadi mahal.

Tahap yang kedua adalah proses pertenunan (weaving). Benang-benang sebagai bahan dasar kain disusun sedemikian rupa sesuai disain konstruksi yang telah ditentukan pada mesin tenun. Kain yang dihasilkan masih berupa kain grey (kain mentah) yang belum layak pakai sehingga harus mengalami beberapa proses kimia dan fisika untuk bisa dipakai.Beberapa ciri dari kain grey antara lain adalah berwarna putih kekuning-kuningan karena masih mengandung pigmen alam,kanji, lemak dari kapas,minyak yang mungkin diberikan pada saat proses dan debu yang menempel selama proses pertenunan.

Tahap yang ke tiga adalah proses pencucian awal (scouring-bleaching). Semua benda asing yang terdapat pada kain grey harus dibersihkan melalui proses tersebut. Proses scouring adalah proses pembersihan kain dari lemak,minyak dan lain-lain dengan larutan kostik soda $37{ }^{\circ} \mathrm{Be}$ pada suhu air mendidih. Sedangkan proses bleaching adalah proses penghilangan pigmen alam dari kapas sehingga menjadi putih bersih agar dapat menyamai warna serat poliesternya dengan memakai zat kimia yang mengandung klorin atau peroksid. Proses ini sangat penting mengingat bahwa kain tersebut terbuat dari dua macam serat campuran kapas dan polyester yang berbeda sifat fisika dan kimianya.

Tahap yang ke 4 adalah proses pemberian warna dasar secara merata dengan cara pencelupan (dyeing). Kain grey yang telah menjadi putih sebagai bahan kain loreng dicelup dengan warna hijau muda atau krem sebagai warna dasar dengan menggunakan zat pewarna campuran dispersi-bejana. Pada akhir tahap ini kain mengalami peregangan ke arah lusi-pakan untuk memulihkan dimensinya.

Tahap yang ke 5 adalah proses printing yaitu proses pemberian warna setempat berdasarkan motif loreng yang telah ditentukan dengan pasta printing.Warna loreng bisanya terdiri dari coklat, hijau dan krem atau merah dengan motif menyerupai semak (dedaunan), khewan (harimau, zebra, jerapah dll.).
Tahap yang ke 6 adalah tahap finishing yang terdiri dari proses steaming-fixatingsoaping-drying. Proses ini bertujuan untuk menyempurnakan hasil-hasil dari proses sebelumnya. Proses steaming-fixating adalah proses penguapan agar terjadi difusi/fiksasi (reaksi) zat warna dengan serat sehingga terikat kuat di dalam serat.Sedangkan proses soapingdrying adalah proses pencucian dan pengeringan yaitu proses penghilangan zat pewarna yang tidak terserap dan tidak bereaksi dengan serat serta semua benda asing yang masih terdapat pada kain, akhirnya kain dikeringkan di dalam mesin pengering/calender.

Kain loreng pada dasarnya adalah kain yang diberi motif loreng yang dibuat dengan cara printing yang terdiri dari tiga warna atau lebih. Kain ini tak ubahnya seperti kain-kain yang diprint seperti kain batik printing, kain motif batik dsb. Hanya saja dibutuhkan persyaratan-persyaratan tertentu agar dapat digunakan untuk kepentingan militer yang berbeda dari bahan tekstil pada umumnya. Kain loreng dituntut mempunyai kualitas yang baik terutama pada ketahanan luntur warna dan kekuatan tarik serta mulurnya mengingat bahwa tujuan penggunaannya

yang berbeda dari pakaian sipil biasa. Demikian pula halnya dengan seragam militer di Indonesia. Setiap kain loreng harus memenuhi persyaratan yang mengacu kepada Standar Nasional Indonesia (SNI) sebagai satusatunya standar yang berlaku secara nasional. Standar Nasional Indonesia (SNI) dirumuskan dan ditetapkan oleh Badan Standarisasi Nasional dengan mengacu kepada World Trade Organization (WTO). Adapun SNI yang dipersyaratkan pada kain loreng dan seragam lainnya untuk kebutuhan militer adalah sbb. :

1. SNI ISO 3801 (2010) - tentang standar berat kain per meter persegi. Berat kain per meter persegi 200 - $300 \mathrm{gr} / \mathrm{m}^{2}$ (katagori sedang). Kain tidak boleh terlalu berat karena akan menyulitkan gerakan si pemakai yang harus fleksibel dalam bergerak terutama di medan tempur. Disamping itu pula membawa peralatan/ perlengkapan penting lainnya seperti senjata,sepatu,topi baja dll. Sebaliknya pula tidak boleh terlalu ringan karena mudah sobek dan mengurangi penampilannya di lapangan.

2. SNI ISO 7211-1 (2010) - tentang anyaman kain. Anyaman kain adalah letak atau posisi 
silang menyilang antara benang lusi dan pakan untuk mendapatkan kekuatan kain yang maksimal. Umumnya ada 2 (dua) macam bentuk anyaman yaitu plat/polos dan satin/keper. Anyaman polos/plat akan menghasilkan dimensi yang lebih stabil serta kekuatan yang tinggi dan mulur yang sedang atau rendah. Kestabilan yang tinggi disebabkan karena terjadi persilangan antara satu helai benang lusi dan satu helai benang pakan yang sangat rapat. Sedangkan anyaman satin akan menghasilkan kestabilan dan kekuatan yang sedang dan mulur yang tinggi. Mulur yang tinggi terjadi karena persilangan antara beberapa helai benang lusi dan satu helai benang pakan atau sebaliknya sehingga posisi benang relatif tidak dalam keadaan rapat sehingga jika mengalami penarikan akan mulur lebih banyak sebelum putus.

3. SNI ISO 7211-2 (2010) - tentang tetal lusi dan pakan per $\mathrm{cm}$ (inci).Tetal lusi adalah jumlah atau banyaknya benang yang tersusun ke arah vertikal/memanjang kain di dalam satuan panjang tertentu $(\mathrm{cm} /$ inci) sedangkan tetal pakan adalah jumlah atau banyaknya helai benang yang tersusun ke arah horizontal/lebar kain di dalam satuan panjang tertentu (cm/inci). Tetal lusi antara 40-50 helai/cm sedangkan tetal pakan antara 2030 helai/cm (katagori sedang). Tetal kain yang terlalu rapat baik ke arah lusi (vertikal) maupun pakan (horizontal) akan menyebabkan kain menjadi kaku sehingga menimbulkan rasa kurang nyaman bagi si pemakai. Sedangkan tetal kain yang terlalu renggang pada ke dua arah akan menyebabkan kain menjadi kendur sehingga dapat mengurangi penampilan dan rasa percaya diri buat yang memakainya.

4. SNI ISO 7211-5 (2010)-tentang Nomor benang lusi dan pakan dalam $\mathrm{Ne}_{1}$ (Tex). Nomor benang adalah ukuran atau besaran benang yang tergantung pada perbandingan panjang dan berat benang dalam satuan $\mathrm{Ne}_{1}$ (Inggris) atau Tex (Jerman).Nomor benang lusi antara $\mathrm{Ne}_{\mathbf{1}} \mathbf{3 5}-\mathbf{4 5} / 2$ dan pakan antara $\mathbf{N e}_{\mathbf{1}}$ 15-25. Konstruksi seperti ini biasa dipakai untuk kain yang terbuat dari serat campuran seperti kapas dan poliester. Ukuran benang yang lebih besar akan membuat kainmenjadi lebih kaku atau keras sehingga selain akan menambah berat kain juga menjadi kurang fleksibel sedangkan ukuran benang yang lebih kecil akan membuat kain menjadi lemas sehingga akan mengurangi penampilan.

5. SNI ISO 13937-1 (2013)-tentang kekuatan sobek kain. Kekuatan sobek kain adalah sejauh mana kain dapat menahan tekanan sebelum sobek dengan alat Uji Elmendorf. Kekuatan sobek arah lusi minimal $38 \mathrm{~N}$ atau 4000 gram sedangkan arah pakan $28 \mathrm{~N}$ atau 3000 gram.

6. SNI 0276 (2009)-tentang kekuatan tarik kain setiap $2,5 \mathrm{~cm}$. Satuan kekuatan tarik kain adalah Newton (N) atau kilogram. Pengujian kekuatan tarik dilakukan pada kedua arah lusi dan pakan dengan panjang $20 \mathrm{~cm}$ diantara kedua titik jepit dan lebar 2,5 cm lalu ditarik sampai putus. Kekuatan tarik arah lusi minimal $440 \mathrm{~N}$ atau $40 \mathrm{~kg} / 2,5 \mathrm{~cm}$ dan arah pakan minimal $240 \mathrm{~N}$ atau $22 \mathrm{~kg} / 2,5$ $\mathrm{cm}$.Sedangkan mulur ke arah lusinya minimal 15 persen dan arah pakan 8 persen. Kekuatan tarik dan mulur ke arah lusi biasanya lebih besar dari pada ke arah pakan. Hal itu terjadi karena ukuran benang -benang lusi biasanya lebih halus namun dirangkap dua sehingga lebih kuat sedangkan benang pakan biasanya tak dirangkap/tunggal.

7. SNI 08-0265-1989-tentang komposisi kain. Segala jenis kain dapat dibuat dengan komposisi dari satu jenis serat atau campuran dua atau lebih serat yang berbeda tergantung pada maksud dan tujuan untuk apa kain itu akan dipakai. Kain yang terbuat dari campuran dua atau lebih serat akan lebih banyak mempunyai keunggulan dari pada satu jenis saja. Salah satu keunggulannya adalah ketahanan kusutnya lebih baik sehingga tampilan kain tak cepat lecek/kusut. Komposisi kain yang dimaksud biasanya terdiri campuran poliester/kapas $65 / 35 \%$ atau sebaliknya tergantung pada kegunaan.

8. SNI ISO 105-C06(2010)-tentang ketahanan luntur warna terhadap pencucian Salah satu syarat penting dari suatu bahan tekstil adalah sifat daya tahan luntur warnanya pada pengujian daya tahan pencucian pada suhu $40^{\circ} \mathrm{C}$ selama 45 menit minimal skala 4 pada Gray scale dan Staining scale baik pada kain pelapis wol maupun poliester.Pengujian ini menjadi sangat penting karena didalam pemakaian sehari-hari harus dicuci agar supaya bersih dan segar kembali untuk dipakai lagi. 
9. SNI ISO 105-E04(2010)-tentang ketahanan luntur warna terhadap keringat Ada 2 (dua) jenis keringat manusia berdasarkan sifat kimianya yaitu keringat yang bersifat asam dan basa (asam/basa lemah). Nilai ketahanan luntur warna terhadap keringat asam maupun basa minimal 4 pada Gray scale maupun Staining scale (pada wol dan poliester).

10. SNI 0288 (2008)- tentang ketahanan luntur warna terhadap gosokan. Setiap kain perlu diuji daya tahan gosoknya terutama kain hasil proses pencapan kerena akan mengalami banyak gosokan seperti penyeterikaan dan gesekan dengan benda lain selama pemakaian baik dalam kondisi kering maupun basah. Pengujian dilakukan terhadap kain uji dengan cara basah dan kering. Adapun nilai ketahanan luntur warna terhadap gosokan basah minimal skala 3 pada Gray scale dan skala 4 pada gosokan kering.

11. SNI 08-0289 (1996)-tentang ketahanan luntur warna terhadap sinar matahari.Prinsip pengujian ketahanan luntur warna terhadap sinar matahari adalah dengan cara menjemur kain contoh uji secara langsung pada waktu terang hari yaitu dari pk.09. ${ }^{\text {oo }}-15 .^{\text {oo }}$ sampai tampak adanya perubahan warna pada kain. Nilai ketahanan luntur warnanya minimal 4 pada skala Blue Wool.

12. SNI 08-0519 (1989) - tentang penggolongan zat warna yang dipakai untuk mewarnai serat poliester. Ada beberapa zar pewarna tekstil yang lazim dipakai untuk mewarnai bahan poliester. Salah satunya adalah Disperse Dyes (zat warna dispersi). Prinsipnya serat poliester bersifat hidrofob, maka agar zat warna dapat terdifusi sampai ke bagian dalam serat harus diwarnai dengan zat warna yang bersifat hidrofob juga. Zat warna dispersi dapat terdifusi di dalam media air yang mengandung pelarut organik (minyak).

13. SNI 08-0621 (1989) - tentang penggolongan zat warna yang dipakai untuk mewarna serat kapas/katun.Ada banyak zat warna tekstil yang dapat dipakai untuk mewarnai serat kapas dari yang memiliki ketahanan luntur sedang sampai tinggi.Pada kegunaan khusus biasanya dipilih zat warna yang sudah terjamin ketahanan lunturnya yaitu Vat Dyes (Indanthreen/zat warna bejana). Prinsipnya serat kapas bersifat hidrofil sedangkan zat warna bejana dapat dibuat hidrofil sementara agar dapat terdifusi ke dalam serat kapas yang pada akahirnya akan dikembalikan lagi menjadi hidrofob.

Bahan, Metoda, Hasil, Pembahasan dan Simpulan

Bahan yang digunakan di dalam penelitian adalah campuran poliester/kapas dengan komposisi 35/65 \%. Kandungan serat kapas yang lebih besar dimaksudkan agar kain tetap mempunyai daya serap air yang tinggi disamping mempunyai sifat daya tahan kusut yang cukup.Hal itu dimaksudkan agar kain tetap nyaman dipakai dan tetap tampilannya baik.

Tabel dibawah ini menunjukkan rancangan/ disain dan komposisi dari kain loreng "Indian Army".

Tabel 1. Disain dan Komposisi Struktur Kain Loreng "Indian Army".

\begin{tabular}{|c|c|}
\hline UNSUR & SATUAN \\
\hline Berat kain & $238,4 \mathrm{~g} / \mathrm{m}^{2}$ \\
\hline Konstruksi & \\
\hline Tetal lusi & $42,8 \mathrm{hl} / \mathrm{cm}$ \\
\hline Tetal pakan & $24,4 \mathrm{hl} / \mathrm{cm}$ \\
\hline Nomor benang lusi & $\mathrm{Ne}_{1} 40 / 2$ \\
\hline Nomor Benang pakan & $\mathrm{Ne}_{1} 15$ \\
\hline Anyaman & Plat/polos \\
\hline Komposisi awal & \\
\hline Poliester & $39,8 \%$ \\
\hline Kapas & $60,2 \%$ \\
\hline
\end{tabular}

Metoda penelitian diawali dari perancangan disain gambar dan anyaman serta konstruksi kain yang diinginkan,pemilihan jenis bahan baku,proses pembuatan kain,proses finishing dan pengujian. Adapun pengujian yang berhubungan dengan kekuatan dan ketahanan luntur adalah;

1. Standar berat kain (dalam : SNI ISO 3801 $\left.\mathrm{g} / \mathrm{m}^{2}\right)$

(2010)

2. Konstruksi :

Tetal lusi/pakan/cm (inci) : SNI ISO 7211-2

(Tex)

(2010)

Nomor benang lusi/pakan : SNI ISO 7211-5

(Tex)

(2010)

Anyaman

SNI ISO 7211-1

(2010)

3. Kekuatan tarik kain $/ 2,5 \mathrm{~cm}$ : SNI $0276: 2009$

Arah lusi/ pakan, N (kg)

Mulur lusi/pakan (\%)

4 Kekuatan sobek kain, : SNI ISO 13937-1

Elmendorf

(2013)

Arah lusi/ pakan, N (g)

5 Komposisi

: SNI 08-0265-1989 
Ketahanan zat warna terhadap

a. Pencucian $40^{\circ} \mathrm{C}$

Perubahan warna

- Penodaan warna pada wol dan poliester

b. Gosokan

- Basah

- Kering

c. Keringat

- Sifat asam

- Perubahan warna

- Penodaan warna pada : wol \& poliester

- Sifat basa

- Perubahan warna

- Penodaan warna pada : wol \& poliester

d. Sinar

: SNI 08-0289

(1996)

7. Golongan zat - Poliester warna pada : - Kapas

SNI

(1989)

SNI

(1989)

08-0519

08-0621

Sampel uji yang digunakan (dipakai oleh salah satu ormas pemuda) adalah "Indian Army” kain loreng eks impor dari India.

Pengujian kekuatan dan ketahanan luntur kain loreng dilakukan di Laboratori- um Penguji Unit Industri Kecil Dinas Perindustrian dan Energi Provinsi DKI Jakarta Jl.Letjen Suprapto Kav.3 Cempaka Putih Jakarta 10510 yang sudah mendapatkan sertifikat akreditas dari Komite Akreditasi Nasional (KAN) LP023 IDN dengan hasil-hasil sebagai berikut :

1. SNI ISO 3801 (2010) - tentang standar berat kain per meter persegi. Berat kain per meter persegi hasil pengujian adalah 238,4 $\mathrm{g} / \mathrm{m}^{2}$. Kain masih termasuk ke dalam katagori berat sedang.

2. SNI ISO 7211-2 (2010) - tentang tetal lusi dan pakan per sentimeter (inci).

Hasil pengujian menunjukkan bahwa tetal lusi adalah 42,8 helai/cm dan tetal pa-kan adalah 24,4 helai/cm.

3. SNI ISO 7211-5 (2010)-tentang Nomor benang lusi dan pakan dalam $\mathrm{Ne}_{1}$. Hasil pengujian menunjukkan bahwa nomor benang lusi adalah $\mathrm{Ne}_{1}$ 40,2/2 dan nomer benang pakannya adalah $\mathrm{Ne}_{1} 15$.

4. SNI ISO 7211-1(2010)-tentang anyaman kain.Hasil pengujian menunjukkan bahwa anyaman kain adalah plat/ribstop.
5. SNI 0276 (2009)-tentang kekuatan tarik kain setiap 2,5 cm. Hasil pengujian kekuatan tarik ke arah lusi sebesar 42,80 kg dan ke arah pakan sebesar 26,42 kg, sedangkan mulur ke arah lusi sebesar 23,71 $\%$ dan ke arah pakan sebesar 12,20\%.

6. SNI ISO 13937-1 (2013)-tentang kekuatan sobek kain. Dari hasil pengujian kekuatan sobek kain kearah lusi menunjukkan angka $4.490 \mathrm{~g}$ dan ke arah pakan sebesar $3.250 \mathrm{~g}$.

7. SNI 08-0265-1989 - tentang komposisi kain. Hasil pengujian komposisi kain menunjukkan bahwa polyester $39,8 \%$ dan kapas $60,2 \%$.

8. SNI ISO105-C06 (2010)-tentang ketahanan luntur warna terhadap pencucian Hasil pengujian ketahanan luntur warna terhadap pencucian $40^{\circ} \mathrm{C}$ selama 45 menit dengan metoda AIM menunjukkan angka 4 pada Gray Scale dan Staining Scale untuk penodaan pada wool maupun pada poliester (kain pembanding).

9. SNI 0288 (2008)- tentang ketahanan luntur warna terhadap gosokan. Hasil pengujian ketahanan luntur warna terhadap gosokan basah menunjukkan angka 2-3 dan gosokan kering menunjukkan angka 3-4.

10. SNI ISO 105-E04 (2010)-tentang ketahanan luntur warna terhadap keringat Hasil pengujian ketahanan luntur warna terhadap keringat asam/basa memberikan masing-masing nilai 4 pada Gray Scale/Skala Abu-abu dan Staining scale/Skala Penodaan.

11. SNI 08-0289 (1996) - tentang ketahanan luntur warna terhadap sinar. Hasil pengujian ketahanan luntur warna terhadap sinar matahari menunjukkan angka 4 pada Blue Wool Scale/Skala Wol Biru.

12. SNI 08-0519 (1989) - tentang penggolongan zat warna pada serat poliester. Hasil pengujian menunjukkan bahwa zat warna yang digunakan untuk mewarnai serat poliesternya adalah zat warna dispersi.

13. SNI 08-0621 (1989) - tentang penggolongan zat warna pada kapas. Hasil pengujian menunjukkan bahwa zat warna yang digunakan untuk mewarnai serat kapas adalah zat warna bejana.

Dari Pengujian yang dilakukan terhadap contoh uji loreng "Indian Army" eks India diperoleh hasil yang sebagiannya dapat 
memenuhi kriteria Standar Nasional Indonesia (SNI) walaupun masih belum maksimal.

1. SNI ISO 3801 (2010) - tentang standar berat kain per meter persegi. Berat kain per meter persegi hasil pengujian adalah 238,4 $\mathrm{g} / \mathrm{m}^{2}$. Secara umum ada tiga jenis kain yang digolongkan berdasarkan berat kain yaitu jenis berat kain ringan, $\left(100-200 \mathrm{~g} / \mathrm{m}^{2}\right)$, kain sedang (200-300 g/m ${ }^{2}$ ) dan kain berat $\left(300 \mathrm{~g} / \mathrm{m}^{2} \mathrm{ke}\right.$ atas $)$.

Berat kain uji $238,4 \mathrm{~g} / \mathrm{m}^{2}$ masih termasuk ke dalam katagori sedang karena masih memenuhi syarat SNI. Berat kain yang kurang dari $200 \mathrm{~g} / \mathrm{m}^{2}$ akan mudah sobek dan mengurangi penampilan di lapangan. Sedangkan berat kain yang lebih besar dari $300 \mathrm{~g} / \mathrm{m}^{2}$ akan menambah beban dan menimbulkan kesulitan bagi si pemakai yang harus bergerak secara fleksibel.

2. SNI ISO 7211-2 (2010)-tentang tetal lusi dan pakan per sentimeter (inci).

Hasil pengujian menunjukkan bahwa tetal lusi $/ \mathrm{cm}$ adalah 42,8 dan tetal pakan $/ \mathrm{cm}$ adalah 24,4. Tetal lusi untuk katagori sedang adalah $40-50$ helai $/ \mathrm{cm}$ sedangkan tetal pakan 20-30 helai/cm. Tetal kain masih dalam katagori sedang dan memenuhi standar SNI. Kain belum terlalu kaku dan masih cukup lembut. Kain dengan tetal yang rendah atau sedikit akan menyebabkan kain menjadi kendur sedangkan kain dengan tetal lusi yang terlalu tinggi atau banyak akan menyebabkan kain menjadi kaku.

3. SNI ISO 7211-5 (2010)-tentang Nomor benang lusi dan pakan dalam $\mathrm{Ne}_{1}$ (Tex). Hasil pengujian menunjukkan bahwa nomor benang lusi adalah $\mathrm{Ne}_{1}$ 42,8/2 dan nomer benang pakannya adalah $\mathrm{Ne}_{1} 15$. Nomor benang masih ideal untuk katagori kain sedang yaitu nomor benang lusi antara $\mathrm{Ne}_{1}$ 35-45/2 dan pakan antara $\mathrm{Ne}_{1}$ 15-25. Untuk memperkuat kain ke arah vertikal maka benang lusi harus dirangkap. Konstruksi seperti ini biasanya dipakai untuk kain yang dibuat dari bahan serat campuran seperti kapas dengan poliester.

4. SNI ISO 7211-1(2010)-tentang anyaman kain.Hasil pengujian menunjukkan bahwa anyaman kain adalah plat/ribstop. Hal ini dimaksudkan untuk mendapatkan kekuatan kain yang maksimal dan dimensi kain yang lebih stabil serta mulur yang
sedang.Anyaman polos/ribstop terjadi karena persilangan antara satu helai benang lusi dan satu helai benang pakan yang sangat rapat. Pemilihan anyaman plat/ polos untuk kain loreng sudah tepat karena menghasilkan kain yang kokoh dan kuat.

5. SNI 0276 (2009)-tentang kekuatan tarik kain setiap 2,5 cm. Hasil pengujian kekuatan tarik arah lusi sebesar 42,80 kg) dan arah pakan sebesar $26,40 \mathrm{~kg}$ sedangkan mulur ke arah lusi sebesar 23,71\% dan ke arah pakan sebesar 12,20 \% . Masih lebih besar dari persyaratan minimal yang ditetapkan $40 \mathrm{~kg} / 2,5 \mathrm{~cm}$ (lusi) dan 20 $\mathrm{kg} / 2,5 \mathrm{~cm}$ (pakan). Sedangkan mulur ke arah lusinya minimal $15 \%$ dan arah pakan $8 \%$. Kekuatan tarik dan mulur ke arah lusi biasanya lebih besar dari pada ke arah pakan. Hal itu terjadi karena ukuran benang-benang lusi biasanya lebih halus namun dirangkap dua agar lebih kuat sedangkan benang pakan biasanya tidak dirangkap/tunggal. Hal ini dimaksudkan untuk mengantisipasi kerena pada umumnya tegangan kain ke arah lusi lebih besar dari pada ke arah pakan di dalam pemakaiannya.

6. SNI ISO 13937-1 (2013)-tentang kekuatan sobek kain. Dari hasil pengujian kekuatan sobek kain ke arah lusi menunjukkan angka $4.490 \mathrm{~g}$ dan ke arah pakan sebesar $3.250 \mathrm{~g}$ yang lebih besar dari persyaratan minimal 4000 gram sedangkan arah pakan 3000 gram. Kekuatan sobek kain menjadi salah satu persyaratan penting untuk semua seragam militer termasuk kain loreng. Kain harus kuat dan tidak mudah sobek mengingat bahwa para angggota militer banyak melalukan gerakan-gerakan fisik baik dalam latihan maupun operasi/perang.

7. SNI 08-0265-1989-tentang komposisi kain. Hasil pengujian komposisi kain menunjukkan bahwa kain terdiri dari poliester 39,8\% dan kapas 60,2\%. Komposisi kain seperti ini dirancang mempunyai daya serap air (misal : keringat) yang tetap tinggi dan bagi si pemakai masih tetap merasakan kesejukan dengan adanya serat kapas yang dominan sedangkan serat poliester akan membuat kain menjadi tidak mudah kusut dan tetap mempunyai sifat "wash and wear" serta kekuatan yang tetap tinggi pula. Pada 
umumnya kain campuran T/C memiliki komposisi 65/35 \% untuk kepentingan sipil/umum (wash and wear) akan tetapi untuk kepentingan militer (khusus) komposisinya dapat terbalik menjadi 35/65 $\%$.

8. SNI ISO 105-C06 (2010) - tentang ketahanan luntur terhadap pencucian. Hasil pengujian ketahanan luntur warna terhadap pencucian pada temperatur $40^{\circ} \mathrm{C}$ selama 45 menit dengan metoda AIM menunjukkan angka 4 sama dengan batas minimal 4 pada Gray Scale maupun Staining Scale. Kedua zat warna yang dipakai (zat warna dispersi dan zat warna bejana) bersifat hidrofob sehingga tidak larut di dalam air yang mengandung sabun standar uji.

9. SNI 0288 (2008)- tentang ketahanan luntur warna terhadap gosokan. Dari hasil pengujian tentang ketahanan luntur terhadap gosokan basah menunjukkan angka 2-3 dan gosokan kering 3-4 dibawah batas minimal 3 (basah) dan 4 (kering) pada Staining Scale. Salah satu kelemahan dari kain printing adalah daya ketahanan gosok, terutama ketahanan gosok basahnya. Hal itu terjadi karena hambatan penetrasi zat pewarna ke dalam serat pada proses printing jauh lebih besar dibandingkan pada proses dyeing sehingga masih cukup banyak zat warna terdapat dipermukaan serat (hanya teradsorpsi) akan tergerus oleh gosokan.

10. SNI ISO 105-E04 (2010)-tentang ketahanan luntur warna terhadap keringat Hasil pengujian ketahanan luntur warna terhadap keringat asam/basa memberikan nilai 4 pada Gray Scale dan Staining Scale. Nilai ketahanan luntur warna terhadap keringat asam maupun basa menurut SNI minimal 4 pada Gray Scale maupun Staining Scale (pada wol/poliester).Maka hasilnya relatip sama.Kedua zat warna yang digunakan sangat tahan terhadap asam atau basa lemah.

11. SNI 08-0289 (1996) - tentang ketahanan luntur warna terhadap sinar. Hasil pengujian ketahanan luntur warna terhadap sinar menunjukkan angka 4 pada Blue Wool Scale, sedangkan nilainya menurut SNI minimal 4 pada Blue Wool Scale. Kedua zat warna memiliki ketahanan luntur warna terhadap sinar yang tinggi.
12. SNI 08-0519 (1989) - tentang penggolongan zat warna pada serat poliester. Hasil identifikasi zat warna yang terdapat pada poliester menunjukkan bahwa zat warna yang digunakan adalah zat warna dispersi.Hal itu terbukti dari uji kelarutan dengan pelarut organik yang larut.Zat warna dispersi adalah zat warna yang paling tepat untuk mewarnai serat poliester karena samasama bersifat hidrofob (SNI).

13. SNI 08-0621 (1989) - tentang penggolongan zat warna pada serat kapas. Hasil identifikasi zat warna yang terdapat pada serat kapas menunjukkan bahwa zat warna yang digunakan untuk mewarnai serat kapas adalah zat warna bejana. Hal itu dibuktikan dari uji kelarutan dengan reduktor natrium hidrosulfit dalam kostik soda. Zat warna bejana bersifat hidrofob namun dapat terserap ke dalam serat kapas yang bersifat hidrofil dengan metoda tertentu. Jika proses pewarnaan dilakukan secara benar maka hasilnya akan sangat baik.

Dari tiga belas persyaratan standar (SNI) yang dipakai untuk sebuah sampel uji kain loreng, dua belas diantaranya telah memenuhi standar dan hanya satu saja yang belum terpenuhi yaitu ketahanan gosok kain baik basah ataupun kering. Salah satu kelemahan dari pada kain printing adalah pada ketahanan gosoknya. Hal itu terjadi karena hambatan yang dialami oleh molekul zat warna untuk berdifusi/fiksasi ke dalam serat jauh lebih besar dibandingkan dengan proses pencelupan (dyeing) akibatnya masih ada molekul zat warna yang teradsorpsi di permukaan serat. Pada saaat kain mengalami gesekan/gosokan zat warna ini akan berpindah ke permukaan benda penggesek.

Dari pembahasan diatas maka dapat disimpulkan bahwa dari tiga belas persyaratan SNI yang dilakukan terhadap contoh uji kain loreng "Indian Army" eks impor dari India, dua belas diantaranya telah memenuhi syarat kecuali satu yaitu ketahanan lunturnya terhadap gosokan yang sedikit masih dibawah standar.

Untuk memperbaiki ketahanan lunturnya terhadap gosokan perlu penelitian tentang proses steaming/fixating terhadap kain printing harus diperhatikan terutama waktu dan temperatur yang diterapkan harus tepat. Hal ini sangat penting agar kualitas produk dapat memenuhi persyaratan SNI. Karena dengan mengatur waktu dan temperatur yang tepat akan 
banyak kesempatan bagi zat pewarna untuk berpenetrasi ke dalam serat polyester maupun kapas.

\section{DAFTAR PUSTAKA}

Kamuflase,2012,Wikipedia-Ensiklopedi Bebas Id.wikipedia.org/wiki/kamuflase.

Loreng, 2012, Wikipedia-Ensiklopedi Bebas Id.wikipedia.org/wiki/loreng

Military Camo Seragam Kamuflase Militer, 2012, Sejarah Perang.com/category/ seragam-kamuflase-militer WikipediaEnsiklopedi Bebas-- Id.wikipedia.org

Multicam standar baru kamuflase militer, 2012, www.eocommunity.com/ shoethread.php?tid=21786

The special fabrics, 2006, Textile for the special purpose, Mc Grew Hill Corp., NewYork., 201

Standar kain seragam TNI, 2010, StandarStandar Kain Khusus,BBIT Bdg., 17

Teknologi Pembuatan Benang, 2007, Teknologi Pemintalan, STT Bandung, 122

Teknologi Pembuatan Kain, 2007,Teknologi Pertenunan, STT Bandung, 104

Teknologi Pencelupan dengan Pewarna Bejana,2007,Teknologi Pencelupan,STTT Bdg., 116

Teknologi Pencapan Pigmen,2008,Teknologi Pencapan dan Penyempurnaan, STT Bdg., 87

Teknologi Finishing,2009, Teknologi Pencapan dan Penyempurnaan,STT Bdg.,93 